\title{
PENGEMBANGAN MEDIA PEMBELAJARAN INTERAKTIF BERBENTUK GAME BERBASIS MACROMEDIA FLASH PRO 8 UNTUK MENINGKATKAN PEMAHAMAN SISWA PADA MATEMATIKA SUB KOMPETENSI DASAR KOMBINASI
}

\author{
Marjan, Khomsatun Nimah \\ Program Studi Magister Pendidikan Matematika Pasca Sarjana Universitas Siliwangi Tasikmalaya \\ ${ }^{1}$ Marjans2unsil@gmail.com
}

\begin{abstract}
This research is a qualitative descriptive study with an experimental method. The purpose of this research is to innovate and develop media in mathematics learning. The research subjects are 3 validators each with 2 material validators, 2 media validators (IT) and 3 user validators (product convenience). The sampling technique uses random sampling techniques taken from teachers who are experts in their fields (certified teachers) and students who are selected randomly. Product trials indicate product friendliness and strength. The advantages of Macromedia Flash-based game products are as follows: 1) Easy games are designed using action scrip 2.0. 2). Games load faster if using the concept between frames. 3) games can be used using labtop and PC. 4). Can be used by using Android-assisted applications. 5) free to choose the object according to the design. 6) free to determine the color of the object. 7) can be used as interactive media. 8). Can be easily published. 9) If the designer is not yet proficient at creating objects can export from an existing file. 10) can be played off line. Whereas the weaknesses of the produck are: 1) slow loading if it is designed using inter-scene concepts. 2). Use other applications that are not available in the software. 3). If you use a labtop with low $\mathrm{R} A M$ specifications the computer is easy to hank. 4) can only be played with swf files if converted to MP4 format the mitigation button does not work. The results showed that the validator assessment of product material should be designed incorrect answers do not return to level 1 but return to the level where questions were answered incorrectly an average score $=90 \%$ which means the combination game product is very valid, can be used without revision. An assessment of the media validator by suggesting that the product is made using a larger fps. therefore the game is made with an initial speed of $12 \mathrm{fps}$ to $30 \mathrm{fps}$ and the resulting score $=92.7 \%$ which means the combination game product is very valid, can be used without revision. While from the user validator / convenience it is recommended that the game should be made with the main object of the game in the form of machine tools with an average score of $85.5 \%$ which means it is very valid, can be used without revision. Of the three data validation results of this combination game product, the average score $=89.4 \%$, which means the combination game product is very valid, can be used without revision
\end{abstract}

Keywords: game, macromedia flash, combination

ABSTRAK
Tujuan penelitian ini adalah untuk inovasi dan pengembangan media pembelajaran matematika Subyek.
penelitian adalah 3 validator masing-masing 2 validator materi, 2 validator media(IT) dan 3 validator
pengguna(kemudahan produk). Teknik pengambilan sample menggunakan teknik random sampling yang
diambil dari guru yang ahli dibidangnya (guru tersertifikasi) dan siswa yang dipilih secara random
sampling. Uji coba produk menunjukan kelemah dan kelebihan produk. Kelebihan produk game berbasis
macromedia flash adalah 1 ) game mudah dirancang dengan menggunakan action scrip 2.0. 2). Game
lebih cepat loading jika menggunakan konsep antara frame. 3) game dapat digunakan dengan
menggunakan labtop dan PC. 4 ). Dapat digunakan dengan menggunakan android berbantuan aplikasi. 5)
bebas memilih obyek sesuai rancangan. 6 ) bebas menentukan warna obyek. 7) dapat digunakan sebagai
media interaktif. 8). Dapat dibublikasikan dengan mudah. 9) Jika perancang belum mahir menciptakan
obyek dapat mengekspor dari file yang sudah ada. 10) dapat dimainkan secara off line. Sedangkan
kelemahan produ adalah, : 1) lambat loading jika dirancang dengan menggunakan konsep antar scene. 2 ).
Menggunakan aplikasi lain yang tidak tesedia di software. 3). Jika menggunakan labtop dengan spesifikasi
ram rendah komputer mudah hank. 4) hanya dapat dimainkan dengan file swf jika dikonvert ke dalam
bentuk mp4 tombol nafigasi tidak berfungsi. Hasil penelitian menunjukan bahwa penilaian validator
materi produk sebaiknya dirancang jewaban salah jangan kembali ke level 1 namun kembali ke level di
mana soal dijawab salah skor rata-rata $=90 \%$ yang bertarti produk game kombinasi Sangat valid, dapat
digunakan tanpa revisi. Penilaian dari validator media dengan menyarankan bahwa produk dibuat
nggunakan fps yang lebih besar. oleh karena itu game dibuat dengan kecepatan awal 12 fps menjadi 30 fps
dan hasil skor nilai = 92,7\% yang berarti produk game kombinasi Sangat valid, dapat digunakan tanpa
revisi. Sedangkan dari validator pengguna/kemudahan disarankan sebaiknya game dibuat dengan obyek


utama game berupa alat-alat mesin dengan rata-rata skor 85,5\% yang berarti Sangat valid, dapat digunakan tanpa revisi. Dari ke tiga data hasil validasi produk game kombinasi ini skor rata-rata $=89,4 \%$ yang berarti produk game kombinasi Sangat valid, dapat digunakan tanpa revisi

Kata Kunci: game, macromedia flash, kombinasi

Submitted Nov 25, 2020| Revised Des 28, 2020| Accepted Des 31, 2020

\section{Pendahuluan}

Di dalam kurikulum 2013 proses kegiatan balajar mengajar bukan mengejar target materi tetapi memaksimalkan proses dalam pembelajaran dan mengembangkan komperensi peserta didik. Dengan proses pembelajaran yang maksimal diharapkan dapat menghasilkan perubahan sikap yang lebih baik. Oleh karena itu baik guru mapun peserta didik harus melakukan kegiatan belajar secara terstruktur secara mandiri baik belajar sendiri atau dalam kelompok (Yamin, 2013).

Menyikapi Undang-undang Nomor 14 tahun 2005 tentang guru dann dosen pasal 4 berbunyi guru sebagai agen pembelajaran berfungsi untuk meningkatkan mutu pendidikan nasional dan pasal 5 berbunyi sebagai agen pembelajaan, pengembang ilmu pengetahuan, teknologi dan seni, serta pengabdi kepada masyarakat berfungsi untuk meningkatkan mutu pendidikan nasional.

Untuk mengembangkan kualifikasi akademik guru menggunakan strategi proses kegiaan pembelajaran sesuai dengan usia, latar belakang siswa dan kompleksitas materi pembelajaran. Pengalaman dalam kegiatan proses belajar mengajar itu menjadi dasar pengembangan model pembelajaran ke arah yang lebih baik. Fungsi media dalam strategi pembelajaran sangat penting untuk ketercapaian tujuan pembelajaran. Dengan pengembangan media pembelajaran diharapkan strategi dan model pembelajaran cocok bagi siswa dan tujuan pembelajaran tercapai. Peranan guru guru dalam memilih media pembelajaran memunculkan ide inovasi kreatif. Dengan pertimbangan teknologi canggih yang dapat diaskes guru dapat menciptakan ide kreatif tesebut. Salah satu inovasi yang dapat diciptakan guru adalah menvisualisasikan konsep matematika yang bersifat ambstrak. Dengan visualisasi ini konsep matematika yang abstrak diharapkan lebih mudah dipahami oleh siswa. Dengan media pembelajaran interaktif berbentukg game diharapkan dapat mendorong siswa untuk berpkir lebih mendalam mengenai bahan ajar yang telah dipelajarinya menggunakan proses berpikir tingkat tinggi ( Analis, evaluasi, dan kreasi ). (Warsono, Hariyanto, 2013). Dengan game yang diciptakan guru dan era digital yang meluas memberikan keluasan kepada siswa untuk menyesuaikan gaya belajarnya. Peranan android untuk memainkan game dalam proses kegiatan belajar mengajar akan lebih menarik dan mempemudah proses kegiatan belajar ini. Kemudahan ini disebabkan karena game dapat diakses melui media elektronik seperti komputer dan android. Dengan kemudahan ini maka game dapat dimainkan di mana saja dan kapan saja. Karena sifatnya yang mudah diakses ini siswa juga dapat menggunakan game sebagai media pembelajaran individu yang serius dan menghibur. Dan dapat mengarahkan siswa pada cara berpikir konvergen yaitu pola berpikir seseorang yang lebih didominasi oleh berfungsinya belahan orak kiri, yaitu berpikir verstikal, sistematik, terfokus serta cenderung untuk meningkatkan pengetahuan yang ada. (Crowl, Sally kaminski, Podell, 1997.). Karena berpikir konvergen menghasilkan respon khusus yang cepat yang sesuai dengan kebenaran dan fakta (Atkinson, Atkinson, Hilgard, 1996) maka media game cocok untuk belajar mandiri, yang memberikan cara berpikir konvergen dengan memberikan respon setiap level game dengan hanya jawaban tunggal yang paling tepat, atau satu-satunya jawaban yang benar (Munandar, 1999).

Kegiatan proses belajar mengajar matematika mempunyai ciri khas dibandingkan dengan mata pelajaran yang lain. Kegiatan penalaran matematika seperti definisi konsep, simbol, bentuk rumus, menurunkan rumus, aplikasi rumus, melibatkan ketrampilan menghitung sehingga benar-salah dalam memecahkan masalah menjadi bertingkat. Jika hal ini tidak ditunjang dengan media yang menarik akan memumculkan minat belajar yang rendah pada beberapa siswa tertentu. Dengan media game diharapkan siswa mempunyai ketertarikan sehingga minat belajar dapat ditingkatkan. Ketertarikan 
media game dapat dirancang dengan kover game, tema game, dan game itu sendiri sebagai alat evaluasi. Di dalam game yang desertakan musik, komposisi warna, obyek game, gelap terang dan gragasi akan menciptakan suasana baru belajar matematika yang bervariasi.

Luasnya materi pembelajaran matematika memungkinkan siswa untuk merasa jenuh dengan konsep, rumus dan hitungan yang rumit. Pada materi kombinasi yang di dalamnya memuat kombinasi dari $\mathrm{n}$ dan seleksi $\mathrm{k}$ unsur untuk $\mathrm{k}=1,2,3,4, \ldots \mathrm{n}$ menggunakan rumus baku yang mudah dicari dan dihafal siswa. Jika dikembangkan pada kombinasi $\mathrm{n}$ unsur dan diseleksi $\mathrm{k}$ unsur dimana unsur dari $\mathrm{n}$ ada yang harus dibuang dan tetap, dan unsur yang diseleksi $\mathrm{k}$ ada unsur $\mathrm{k}$ yang harus dibuang dan tetap maka pemahaman ini perlu penekanan tertentu pada siswa.

Game dirancang untuk 10 level dengan masalah kombinasi yang berbeda-beda. Dari level 1 sampai dengan level 10 dirancang dari masalah yang sederhana sampai dengan masalah yang kompleks. Produk media untuk proses pembelajaran kombinasi ini akan dikembangkan dalam bentuk game berbasis macro media flash pro 8. Game dirancang dengan tema olah raga panahan dimana terdapat seorang mualaf yang hendak mencari guru bertemu dengan iblis yang melarang dan menghalangi pemuda itu. Pemuda itu kemudian memanah iblis dan iblis menawarkan kepada pemuda. Jika dapat memanah dengan tepat 10 kali dengan tepat, maka pemuda itu dapat bertemu dengan guru. Karena pemuda itu ingin bertemu dengan guru agar keyakinan sebagai mualaf bertambah kuat. Sebelum berangkat ibunya perpesan, jika di jalan terdapat rintangan, maka pemuda itu harus mengucapkan bismillah sehingga ibu akan mengirimkan bantuan dalam bentuk cara memecahkan masalah sehingga pemuda dapat membidik dengan tepat rintangan iblis itu. masalah setiap level dari game yang dirancang adalah masalah yang berhubungan dengan masalah memecahkan kombinasi.

Media game ini dirancang dengan tujuan (1) siswa memilih rumus yang tepat dalam memecahkan masalah kombinasi; (2) siswa dapat menentukan unsur $\mathrm{n}$ yang tetap dan unsur $\mathrm{n}$ yang dibuang; (3) siswa dapat menentukan unsur $\mathrm{k}$ yang tetap dan usur k yang dibuang; (4) siswa dapat menghitung ilmu hitung vaktorial;(5) siswa dapat menerapkan konsep kombinasi dalam kehidupan sehari-hari

\section{Metode Penelitian}

Metode penelitian ini menggunakan penelitian pengembangan Research and Development( R\&D) DENGAN) dengan tujuan untuk menghasilkan media pembelajaran dan menguji kelayakan media. Penelitian dilaksanakan pada bulan Juni 2020 di SMK YPE Sampang Kabupaten Cilacap Jawa Tengah. Target/sasaran penelitian adalah terbentuknya media pembelajaran dalam bentuk game berbasis macro media flash pro 8 yang valid dengan subjek penelitian adalah validator yang Conten validity, Construck validity, dan face validity, Validasi soal pemahaman matematik, Melaksanakan tes pemahaman matematik. Prosedur penelitian dirancang dengan menggunakan langkah-langkah yang sistematik yang ditetapkan oleh Borg dan Gall 1994 (Sugiyono, 2009) sebagai berikut :

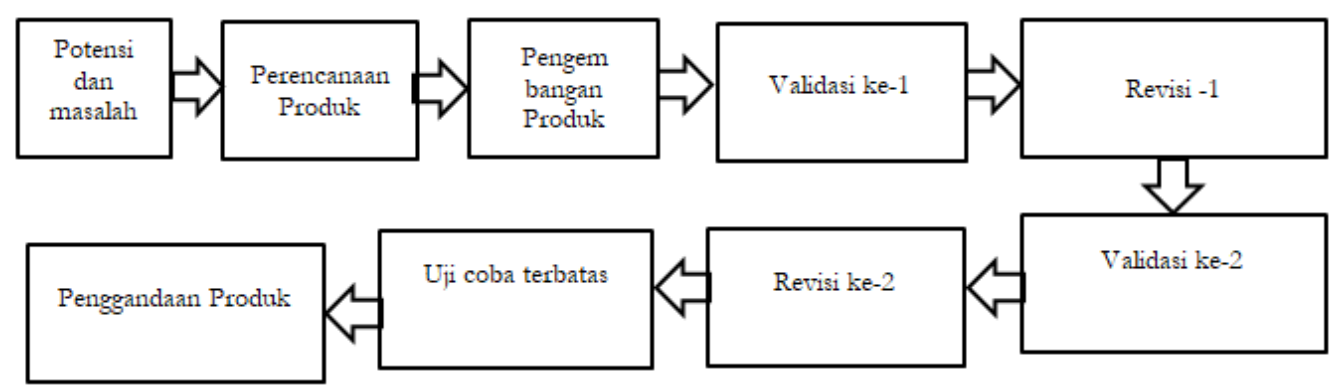

Gambar 1. Langkah-langkah Brog dan Gall

Rencana produk dibuat dengan merancang susunan game mulai dari cover game berjudul game panahan kombinasi, tujuan bermain game, materi pembelajaran, contoh memecahkan game, petunjuk 
memainkan game, tema dan cerita munculnya gamem bantuan menjawab soal, pemberitahuan jawaban benar, pemberitahuan jawaban salah. Rencana game juga memuat tokoh game, propertis game dan warna. Semua perencanaan produk dibuat dalam stpry board.

Pengembangan produk dilakukan berdasarkan story board yang telah dirancang yang diterjemahkan ke dalam bentuk visual menggunakan soft ware macromedia flash pro 8. Dalam pengembangan ini juga disertakan tombol-tombol navigasi yang berfungsi untuk berpindah dari starger satu ke starger berikutnya. Untuk menyesuaikan waktu dan kapasitas komputer juga dikembangkan model rancangan animasi menggunakan anatar scene dan antar frame. Game dibuat dengan kecepatan $10 \mathrm{fps}$

\section{Hasil dan Pembahasan}

1. Hasil Pengembangan Produk game

Rancangan game yang telah dibuat produk adalah sebagai berikut :

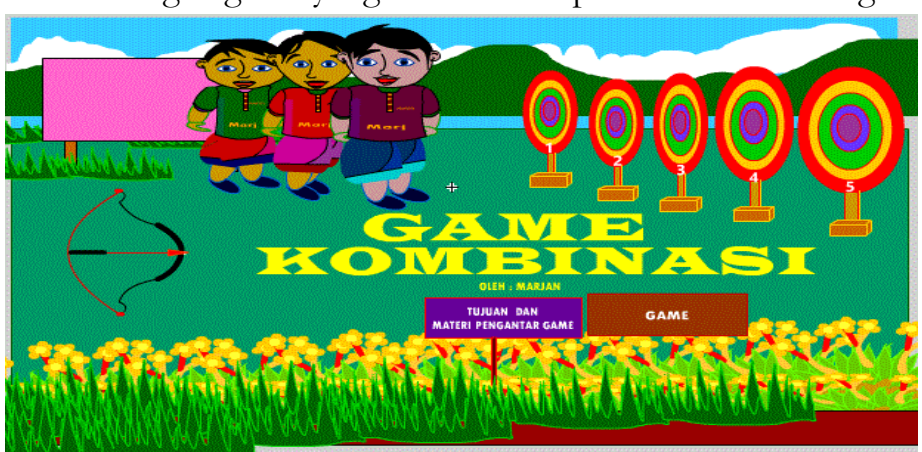

Gambar 2. Cover game

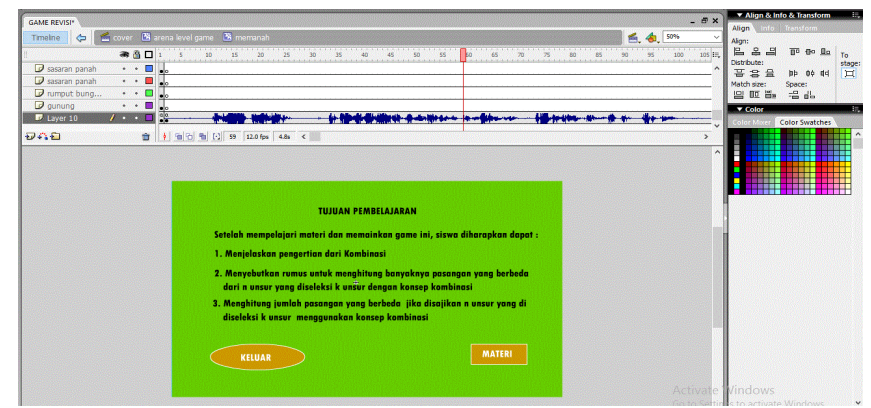

Gambar 3. tujuan pembelajaran/game

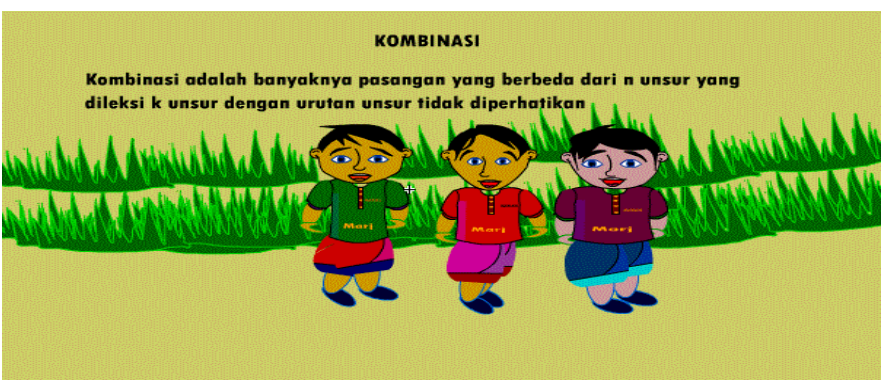

Gambar 4. Materi
Judul produk/cover game Kombinasi panahan

Tampilan Tujuan Game

Tampilan materi dalam game yang dikembangkan 


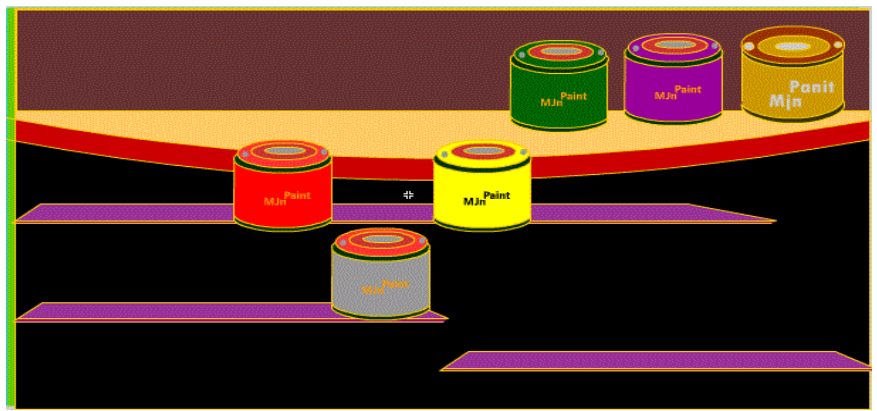

Gambar 5. Mencampur cat

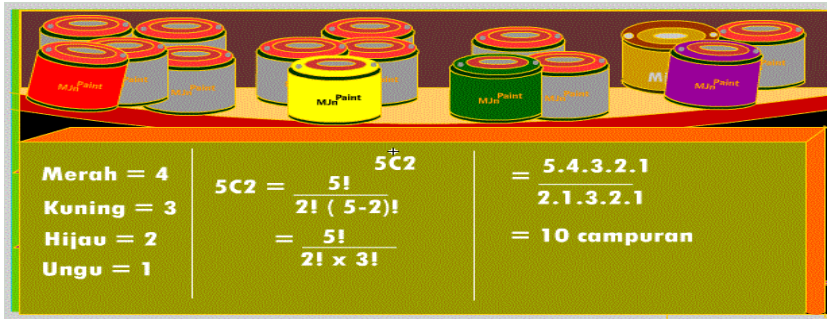

Gambar 6. contoh soal

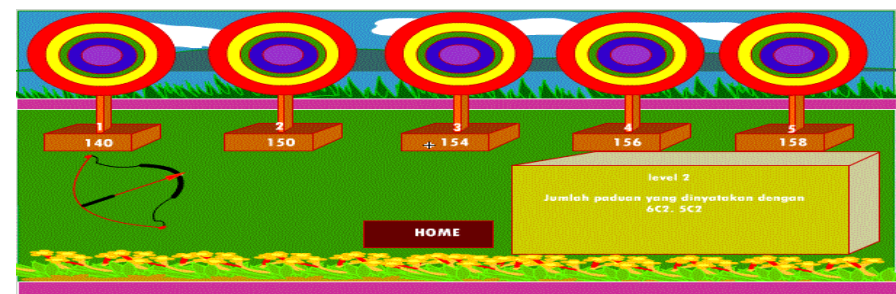

Gambar 7. game level 1

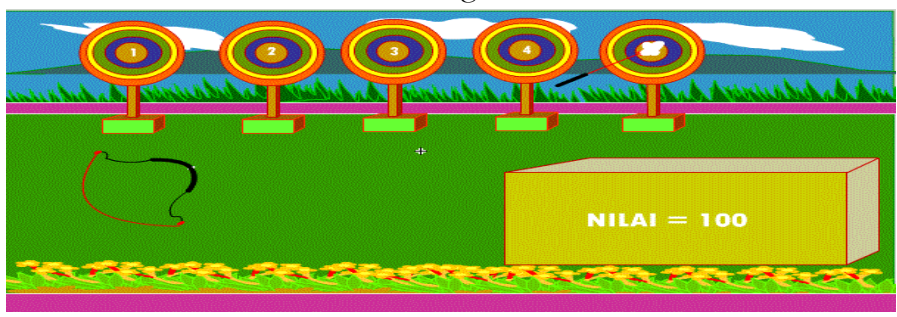

Gambat 8. Pemberitahuan jawaban benar

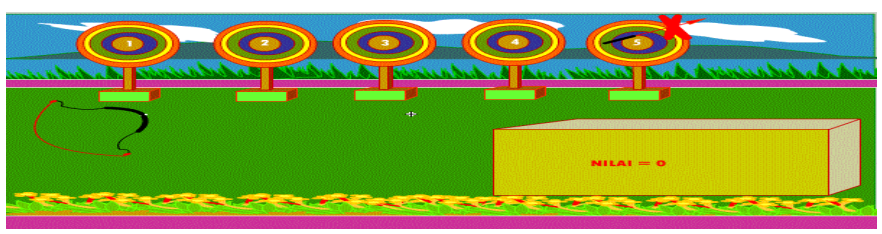

Gambar 9. Gambar pemmberitahuan jawaban salah

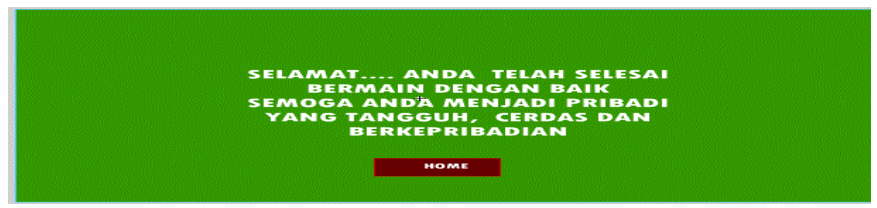

Gambar 10. Penup Game
Animasi model kontekstual materi kombinasi pencampuran cat dengan warna yang berbeda

Contoh soal yang dikembangkan

Level game yang dikembangkan

Skor akhir akhir dari game yang dibuat

Pemberitahuan jawaban yang salah

Tampilan jika game berakhir 
2. Hasil validasi produk game

Dari produk game yang dihasilkan divalidasi dengan hasil validasi sebagai berikut, dan hasilnya sebagai berikut:

Tabel 1. hasil rata - rata penilaian content validity

\begin{tabular}{|c|c|c|c|}
\hline No. & Aspek penilaian & Deskriptor & Skor \\
\hline \multirow[t]{6}{*}{1} & \multirow[t]{6}{*}{ Relevansi } & $\begin{array}{l}\text { Materi relevan dengan kompetensi yang harus dikuasai } \\
\text { siswa }\end{array}$ & 5,0 \\
\hline & & $\begin{array}{l}\text { Media pembelajaran interaktif berbentuk game berbentuk } \\
\text { macro media flash pro } 8 \text { relevan dengan yang harus } \\
\text { dikuasai }\end{array}$ & 4,5 \\
\hline & & $\begin{array}{l}\text { Kelengkapan materi sesuai dengan tingkat perkembangan } \\
\text { siswa }\end{array}$ & 4,0 \\
\hline & & Materi cukup memenuhi tuntutan kurikulum & 4,5 \\
\hline & & $\begin{array}{l}\text { Ilustrasi media sesuai denagn tingkat perkembangan } \\
\text { siswa }\end{array}$ & 4,5 \\
\hline & & Ilustrasi media yang fungsional cukup & 4,5 \\
\hline \multirow[t]{4}{*}{2} & \multirow[t]{4}{*}{ Keakuratan } & Materi yang disajikan sesuai dengan kebenaran keilmuan & 4,5 \\
\hline & & Materi yang disajikan sesuai perkembangan mutakhir & 4,0 \\
\hline & & Materi yang disajikan sesuai dengan kehidupan sehari-hari & 5,0 \\
\hline & & $\begin{array}{l}\text { Pengemasan materi dalam media sesuai denagan } \\
\text { pendekatan keilmuan yang bersangkutan (pendekatan } \\
\text { saintifik) }\end{array}$ & 4,5 \\
\hline 3 & $\begin{array}{l}\text { Kelengkapan } \\
\text { sajian }\end{array}$ & Menyajikan kompetensi yang harus dikuasai siswa & 4,5 \\
\hline \multirow[t]{2}{*}{4} & \multirow{2}{*}{$\begin{array}{l}\text { Konsep dasar } \\
\text { materi }\end{array}$} & Kesesuaian konsep kombinasi & 4,5 \\
\hline & & Kesesuaian konsep soal didalam game & 4,5 \\
\hline \multirow[t]{5}{*}{5} & \multirow{4}{*}{$\begin{array}{c}\text { Kesesuaian sajian } \\
\text { dengan runtutan } \\
\text { pembelajaran yang } \\
\text { terpusat pada } \\
\text { siswa } \\
\end{array}$} & Mendorong keingintahuan siswa & 4,5 \\
\hline & & Mendorong terjadinya interaksi siswa & 4,5 \\
\hline & & Mendorong siswa membangun pengetahuannya sendiri & 4,5 \\
\hline & & Mendorong siswa belajar secara kelompok & 4,5 \\
\hline & Jumlah & & 76,5 \\
\hline
\end{tabular}

Prosentase skor $=76,5 / 85 \times 100=90 \%$, dengan demikian bahwa hasil validator conten memnuhi kriteria valid dan layak untuk digunakan. Hasil validator materi adalah seabgai berikut:

Tabel 2. Jumlah skor rata-rata valiasi materi

\begin{tabular}{|c|c|c|c|}
\hline $\mathrm{NO}$ & Aspek penilaian & Deskriptor & Skor \\
\hline \multirow[t]{6}{*}{1} & \multirow[t]{6}{*}{ Tampilan umum } & Desain media sesuai denagan materi kombinasi & 5,0 \\
\hline & & $\begin{array}{l}\text { Desain media sesuai dengan konsep multimedia } \\
\text { berbasis game }\end{array}$ & 5,0 \\
\hline & & $\begin{array}{l}\text { Pengemasan media terintegrasi antara tujuan, } \\
\text { materi inti dan evaluasi yang dikemas dalam } \\
\text { bentuk game }\end{array}$ & 5,0 \\
\hline & & Desain media menarik untuk dilihat & 4,5 \\
\hline & & $\begin{array}{l}\text { Desain media menyajikan contoh kontekstual } \\
\text { kombinasi }\end{array}$ & 5,0 \\
\hline & & $\begin{array}{l}\text { Desain media menyajikan pemanfaatan berbagai } \\
\text { software dan aplikasi }\end{array}$ & 5,0 \\
\hline \multirow[t]{4}{*}{2} & \multirow[t]{4}{*}{ Tampilan khusus } & Pemilihan warna dalam media & 4,0 \\
\hline & & Pemilihan media yang unik & 4,0 \\
\hline & & $\begin{array}{l}\text { Memuat integrasi konsep kombinasi dan } \\
\text { kontekstual pencampuran benda/ objek }\end{array}$ & 5,0 \\
\hline & & $\begin{array}{l}\text { Memuat game yang berkaitan dengan konsep } \\
\text { kombinasi }\end{array}$ & 5,0 \\
\hline 3 & Penyajian media & $\begin{array}{l}\text { Tampilan media menarik dan mudah dimainkan } \\
\text { dengan menggunakan CPU, laptop, dan android }\end{array}$ & 3,0 \\
\hline
\end{tabular}




\begin{tabular}{llc}
\hline & Terdapat judul/ keterangan media & 5,0 \\
\cline { 2 - 3 } & Terdapat cara memainkan game & 5,0 \\
\cline { 2 - 3 } & $\begin{array}{l}\text { Dilengkapi dengan tombol navigasi yang } \\
\text { lengkap }\end{array}$ & 5,0 \\
\cline { 2 - 2 } & $\begin{array}{l}\text { Penyajian media mampu mengembangkan minat } \\
\text { belajar siswa }\end{array}$ & 4,0 \\
\hline Jumlah & & 69,5 \\
\hline
\end{tabular}

Prosentase skor $=69,5 / 75=92,7 \%$, dengan demikian validator menilai bahwa media yang dibuat layak untuk digunakan. Terakhir penilaian terhadap valiasi media, hasilnya sebagai berikut:

Tabel 3. Jumlah skor rata-rata valiasi media

\begin{tabular}{|c|c|c|c|}
\hline $\mathrm{NO}$ & Aspek penilaian & Deskriptor & Skor \\
\hline \multirow[t]{6}{*}{1} & \multirow[t]{6}{*}{ Loading } & Kecepatan loading & 5,0 \\
\hline & & $\begin{array}{l}\text { Desain media sesuai dengan tingkat kelas (umur } \\
\text { siswa) }\end{array}$ & 4,0 \\
\hline & & $\begin{array}{l}\text { Pengemasan media terintegrasi dengan jelas yang } \\
\text { memuat tujuan, materi inti dan evaluasi yang } \\
\text { dikemas dalam bentuk game }\end{array}$ & 3,75 \\
\hline & & Desain media menarik untuk dilihat & 4,0 \\
\hline & & $\begin{array}{l}\text { Desain media menyajikan contoh kontekstual } \\
\text { kombinasi }\end{array}$ & 4,7 \\
\hline & & $\begin{array}{l}\text { Dapat digunakan dengan Android dengan aplikasi } \\
\text { yang mudah dan ringan }\end{array}$ & 4,0 \\
\hline \multirow[t]{4}{*}{2} & \multirow[t]{4}{*}{ Tampilan khusus } & Pemilihan warna dalam media & 5,0 \\
\hline & & Pemilihan media yang unik & 4,3 \\
\hline & & $\begin{array}{l}\text { Contoh soal yang dituangkan dengan konsep } \\
\text { animasi }\end{array}$ & 4,0 \\
\hline & & $\begin{array}{l}\text { Memuat game yang berkaitan dengan konsep } \\
\text { kombinasi }\end{array}$ & 4,0 \\
\hline \multirow[t]{6}{*}{3} & \multirow[t]{5}{*}{ Penyajian media } & $\begin{array}{l}\text { Tampilan media menarik dan mudah dimainkan } \\
\text { dengan menggunakan CPU, laptop, dan android }\end{array}$ & 3,7 \\
\hline & & Terdapat judul/ keterangan media & 4,7 \\
\hline & & Terdapat cara memainkan game & 4,7 \\
\hline & & Dilengkapi dengan tombol navigasi yang lengkap & 4,3 \\
\hline & & $\begin{array}{l}\text { Penyajian media mampu mengembangkan minat } \\
\text { belajar siswa }\end{array}$ & 4,0 \\
\hline & Jumlah & & 64,15 \\
\hline
\end{tabular}

Perhitungan akhir skor rata-rata $=64,15 / 75 \times 100 \%=85,5 \%$, dengan demikian media yang dikembangkan layak digunakan. Penelitian pengembangan ini menggunakan langkah-langkah yang dikemukakan oleh Borg dan Gall 1994 (Sugiyono, 2009). Berdasarkan penilaian validator materi catatan untuk produk yang telah dibuat sebaiknya dirancang jawaban salah jangan kembali ke level 1 namun kembali ke level di mana soal dijawab salah skor rata-rata $=90 \%$ yang bertarti produk game kombinasi Sangat valid, dapat digunakan tanpa revisi. Penilaian dari validator media dengan catatan, menyarankan bahwa produk dibuat nggunakan fps yang lebih besar. oleh karena itu game dibuat dengan kecepatan awal $12 \mathrm{fps}$ menjadi $30 \mathrm{fps}$ dan hasil skor validasi materi $=92,7 \%$ yang berarti produk game kombinasi Sangat valid, dapat digunakan tanpa revisi. Sedangkan dari validator pengguna/kemudahan dengan catatan menyaarankan bahwa sebaiknya game dibuat dengan obyek utama game berupa alat-alat mesin dengan rata-rata skor validasi kemudahan $=85,5 \%$ yang berarti Sangat valid, dapat digunakan tanpa revisi. Dari ke tiga data hasil validasi produk game kombinasi ini skor rata-rata $=89,4$ yang berarti produk game kombinasi sangat valid, dan dapat digunakan tanpa revisi. 


\section{Kesimpulan}

Dari hasil penelitian Pengembangan media internatif berbentuk game berbasis macromedia flash dapat disimpulkan bahwa produk game yang dirancang dan diterjemahkan ke dalam bentuk game menggunakan soft ware macromedia flash pro 8 mempunyai tingkat validitas sebagai berikut : Validitas materi $=90,0 \%$, Validitas media $/ \mathrm{IT}=92.7 \%$, Validitas kemudahan $=85,5 \%$, Dan nilai ratarata validasi $=89,4 \%$. Hal ini menunjukan bahwa game dapat digunakan sebagai media pembelajaran matematika sub kopetensi dasar kombinasi pada kelas XI SMK YPE Sampang Cilacap Jawa Tengah.

\section{Daftar Pustaka}

Atkinson, R., Richard, A., Hilgard, E. (1996). Introduction to psychology. New York: Harcourt Brace College Publishers.

Crowl, Thomas K,. Sally Kaminsky and david M. Podell. (1997). Educational psychologiy: windows on teaching. Dubuque: Brown and Benchmark

Munandar, S.C. Utami. (1999). Kreativitas dan Keberbakatan. Jakarta: Gramedia Pustaka Utama

Sugiyono. (2009). Metode Penelitian Kuantitatif, Kualitatif dan R\&D. Bandung : Alfabeta

Undang - undang No. 14 tahun 2005, tentang guru dan dosen pasal 10 ayat (1), guru dan dosen harus memiliki kompetensi pedagogik, kompetensi kepribadian, kompetensi sosia, dan kompetensi profesional.

Undang - undang No. 14 tahun 2005, tentang guru dan dosen pasal 10 ayat (8) dan guru dan dosen memiliki kesempatan untuk mengembangkan dan meningkatkan kualifikasi akademik dan/atau (9) memperoleh pelatihan dan pengembangan profesi dalam bidangnya.

Warsono, dan Hariyanto. (2013). Pembelajaran Aktif: Teori dan Asesmen. Bandung: PT Remaja Rosdakarya.

Yamin, M. (2013).Strategi dan Metode dalam Model Pembelajaran. Jakarta: Referensi (GP Press Group).

https://www.adobe.com, Macromedia- Flash : Flash 8 realease Note-Adobe

https://www.macromedia_flash-8.soft32.com, Downl,oad Macromedia Flash 8 free

https://www.teacherclick.com, Macromedia Flash 8 Free Tutorial. Introduction Flash-Kompasiana.com

https://www.hanifsulistiyo.wordpress,com, Macromedia Flash, - pengertian, sejarah kelebihan dan kekurangan, (2018)

https://www.academia.edu,"makalah pembelajaran matematika, Marta Nila Sari

https://www.gurudigital.id pengertian, contoh \& software pembuat media Pembelajaran Interaktif, Ibu Adji 2017

https://endonesa.wordpress.com media interaktif- oleh edonesia-wordPress. 